\title{
Species diversity of different insect families trapped under beer-based volatile fermentation
}

\author{
Mazher Farid lqbal ${ }^{1,2}$ (i) and Yu-Long Feng ${ }^{1 *}$ (D)
}

\begin{abstract}
Background: Insect species composition is an important phenomenon playing a significant role in the ecosystem. Chemical control of insects and pests releases toxic materials to the environment. These chemicals are dangerous to human populations. In this situation, there is a dire need to develop strategies to overcome the haphazard use of chemicals. The present investigations were carried out to explore the diversity of different insects attracted through bait fermentation.

Methods: The traditionally prepared bait fermentation was used to attract different insect populations both in treated (traps installed near field crops) and control traps (traps installed near invasive weed). Abundance, evenness, richness and equitability of these trapped insects were calculated. The chemical screening of bait fermentation was done using Gas Chromatography and Mass Spectrometry (GC-MS).

Results: Significant difference $(P<0.05)$ in abundance of insect populations was found in treated compared to control trap. The insects of Noctuidae family recorded high Shannon-Wiener's diversity index followed by Muscidae. Margalef's index was recorded maximum in the treated traps (10.77) compared to those of control (8.09). The yielded index indicated that maximum richness was found in bait treated compared to control. The Shannon's equitability's values were investigated higher in Noctuidae (1.48), while, maximum evenness was observed in Muscidae (2.05) in treated trap. This fermentation was dried at room temperature and ground at 0.1 micron size. Our result showed significant $(P<0.05)$ effects of extraction times, with high yield in first extraction by polar solvents. Co-efficient of determination $\left(R^{2}=0.87\right)$ recorded similar results in both extractions, however high root mean square error $(0.97)$ recorded with bait + distilled water solvent showed linear arc line gave better performance. Finally, this fermentation was analyzed using GC-MS and recorded volatile compounds that were involved in the attraction of major and minor pests.

Conclusion: Fermentation can help for the attraction of different families of insects of various crops. The field experiment suggested that this fermentation is economical, easily installed and consumed only 0.64 RMB/0.09 USD, including infrastructures per location. Bait fermentation is safe biochemical constituents and did not spread any toxic chemicals to the environment.
\end{abstract}

Keywords: Adult insect attraction, Bait traps, Bioactive compounds, Diversity indices, Gas Chromatography and Mass Spectrometry

\footnotetext{
*Correspondence: fyl@syau.edu.cn

${ }^{1}$ Liaoning Key Laboratory for Biological Invasions and Global Changes,

College of Bioscience and Biotechnology, Shenyang Agricultural

University, Shenyang 110866, Liaoning Province, People's Republic

of China

Full list of author information is available at the end of the article
}

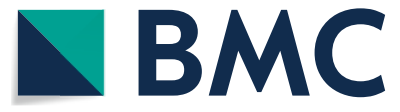

(c) The Author(s) 2020. This article is licensed under a Creative Commons Attribution 4.0 International License, which permits use, sharing, adaptation, distribution and reproduction in any medium or format, as long as you give appropriate credit to the original author(s) and the source, provide a link to the Creative Commons licence, and indicate if changes were made. The images or other third party material in this article are included in the article's Creative Commons licence, unless indicated otherwise in a credit line to the material. If material is not included in the article's Creative Commons licence and your intended use is not permitted by statutory regulation or exceeds the permitted use, you will need to obtain permission directly from the copyright holder. To view a copy of this licence, visit http://creativeco mmons.org/licenses/by/4.0/. The Creative Commons Public Domain Dedication waiver (http://creativecommons.org/publicdomain/ zero/1.0/) applies to the data made available in this article, unless otherwise stated in a credit line to the data. 


\section{Introduction}

Synthetic pesticides are frequently used in agriculture to control different types of insects in the world. These pesticides are creating resistance against diversified insectpests in maize, millet, soybean, sunflower, sesame and vegetable crops. These synthetic organic compounds spread toxic chemicals in the environment [1-4]. These toxic chemicals are causing respiratory diseases, skin itchiness, redness, and cardiovascular diseases, in human beings during the hand or aerial spray process [5-9]. These are also toxic to live stocks and birds because they are highly abundant dwellers of the field crops $[10,11]$. In this situation, there is a dire need to develop suitable strategies to control insects of different field crops. Biological control agents, phytochemicals, pheromone traps, light traps and bait traps are helpful to manage this disaster [12-22]. Our present research played a vital role to attract the insects of different crops. Fermentation used to defeat this problem and acted like pheromone traps was made up of rotten fruits mixed with beer and brown sugar. The bait trap attracted the moths of different insect families [23-25]. Likewise, the primary sex pheromone was found in 1959 [26] and the insects of Lepidoptera were attracted by the sex pheromones [27]. In our experiment bait fermentation attracted both sex of various insects. Consequently, bait fermentations provide benefit over sex pheromones, because they can vwwb used for targeting a wide range of insects. Therefore, several trapping methods based on pheromones and kairomones are already in use for managing insects using different fermentations. So, food-based baits are an effective technique for insect control.

Firstly we hypothesized that abundance, richness and evenness of different insect families increased through using fermentation. Moreover, the yield would be great in the first extraction recorded after drying of each fermented solvents. Finally, GC-MS screening of bait fermentation may contain various volatile chemical constituents that can be involved in attraction of insect populations. How many insect families could be attracted by bait fermentation in both treatments and also how many chemicals could be screened out from fermentation through GC-MS technique? The current study was aimed to determine the abundance, richness, evenness, and equitability of the insect families attracted by fermentation. Moreover, the study also evaluated dried baits eluted with different solvents. However, coefficient of determination $\left(R^{2}\right)$ was calculated and compared to root mean square error (RMSE). Finally traditionally prepared sugar fermented fruit bait was analyzed using GC-MS after eluted by low and high polar solvents, and chemical activities of identified bioactive compounds were discussed with available literature.

\section{Methods}

The present investigations were carried out to evaluate ecological indices such as abundance, evenness and species richness of different insects diversified in mountainous areas of Shenyang Agricultural University. The studied vicinity having $41.8282^{\circ} \mathrm{N}$ and $123.5647^{\circ} \mathrm{E}$ is the northeastern part in China edges South Korean borderline [28].

\section{Preparation of fermentation}

The fermentation contained $500 \mathrm{~g}$ rotten fruits (banana, apple and peach taken in same quantity), was ground in $1 \mathrm{~L}$ distilled water $(\mathrm{pH} 7.3)$ and mixed in blender until homogenized [29-31]. This material was put in a $5 \mathrm{~L}$ plastic bottle, in which $330 \mathrm{~mL} \mathrm{4 \%}$ beer was added. One kilogram of brown sugar was mixed in this solution and stirred gently. The contents were preserved at room temperature $\left(27^{\circ} \mathrm{C}\right)$, stirred regularly, after 10 days the fermentation was ready for use.

\section{Installation of traps}

Paired traps were installed near the cropped area (treatment) along with non cropped area (control) at forth week of August by transect walk method in three different locations and repeated with three times. "Approximately" $25 \mathrm{~mL}$ fermentation was used in each pot fixed in the bottom of the trap and two $11 \mathrm{~cm}$ filter papers were placed on upper layer of bait fermentation to provide a suitable helipad for sucking of the adult insects. Each trap was $34 \mathrm{~cm}$ long, $20 \mathrm{~cm}$ wide, round shaped in which $20 \mathrm{~cm}$ funnel/cone-shaped body sieve was attached having $4 \mathrm{~cm}$ hole for trapping the insects (Fig. 1).

\section{Data collection}

The sampling was carried out from last week of August to last week of September. Each trap having various insects' populations as taken into the laboratory, preserved at $-36^{\circ} \mathrm{C}$ for killing these insects for $2 \mathrm{~h}$. These insects were stored for subsequent laboratory processing comprising identification, drying, spreading, pinning, photographing and labeling. Difficult insect's specimens were identified with the consultation of the Entomological Department of Shenyang Agricultural University, Shenyang.

The image depicted in Fig. 1 along with graphical abstract are my own data.

The attracted insects sucked the sap from the bait fermentation, moved in upward direction and trapped through hole.

\section{Calculation of insect diversity}

All the trapped insects were separated family-wise, counted separately and calculated diversity of insects 


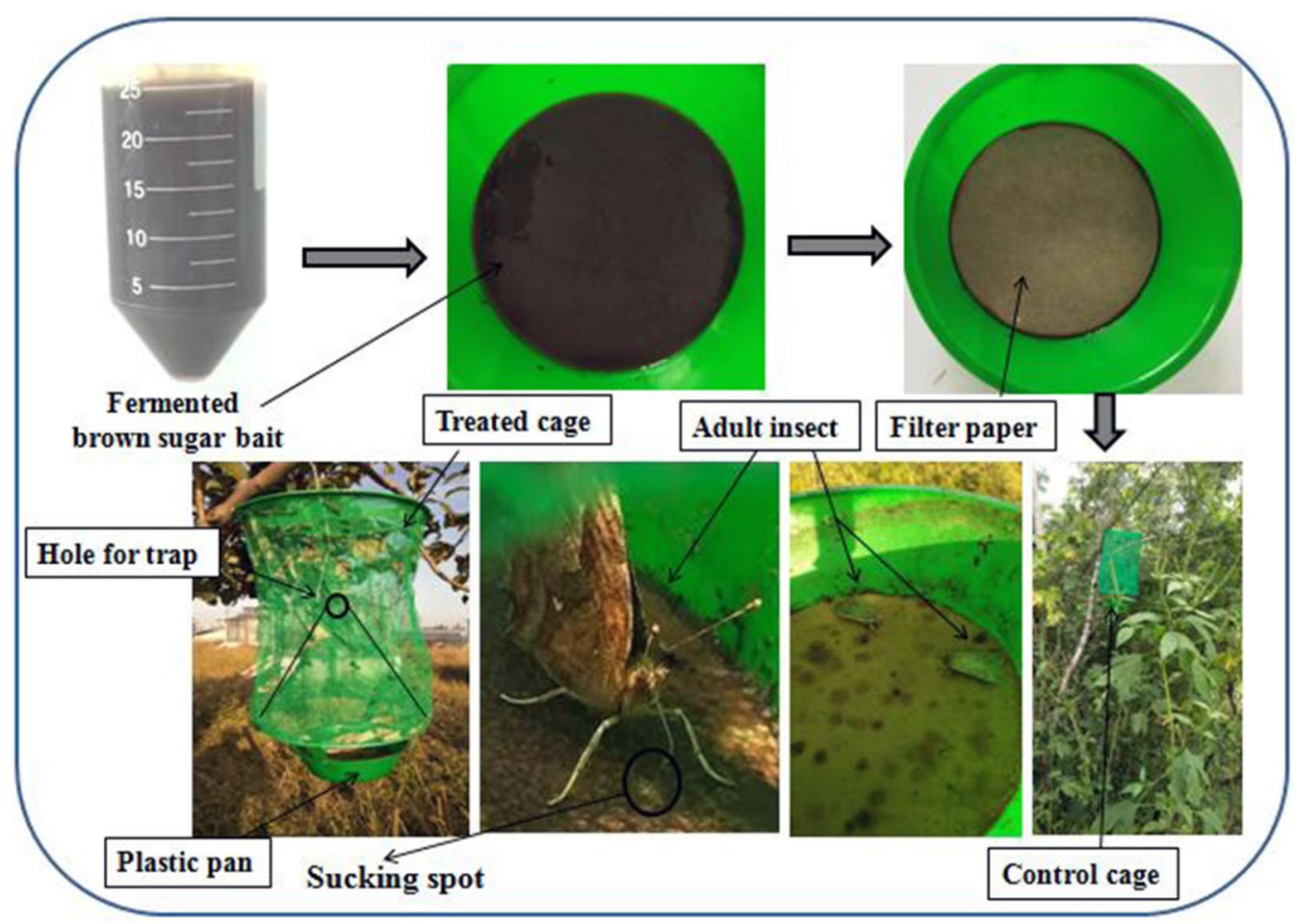

Fig. 1 Graphical installation of bait fermentation traps

such as richness, abundance and evenness compared to control. Insects diversity measured by Shannon-Wiener's diversity index, Simpson's index, Margalef's index and Shannon's equitability index [32-36].

\section{Sample extraction from bait material}

The bait fermentation was well dried at room temperature $\left(27^{\circ} \mathrm{C}\right)$ and ground gently with pestle and mortar keeping in view the particle size up to 0.1 micron. Methanol and distilled water were used at $4 \mathrm{~mL} \mathrm{~g}^{-1}$ of bait sample; kept for 3 days at room temperature for completion of solvent extraction by maceration method. The waste of bait produced after first extraction reused according to the above procedure and get second extraction and repeated this process for getting third extraction. Each solvent extracts were filtered and dried at room temperature to remove the solvents from the eluents. The first, second and third time extracted dried samples were weighed separately, mixed together, and stored at $4{ }^{\circ} \mathrm{C}$ in airtight glass bottles for further use [37]. Physical properties of each extract (color, stickiness and appearance) were recorded visually (Table 1 ).

\section{Sample preparation for GC-MS screening}

Approximately $10 \mathrm{mg}$ dried sample collected from each solvent extract was accurately weighed and put in the centrifuge tube, in which $1 \mathrm{~mL}$ of HPLC grade methanol was added to dissolve the sample and vortexed for 2-3 min. About 0.2 g Graphitized carbon black (GCB) was added into the solution and vortexed for $1 \mathrm{~min}$ to remove the pigmentations and sterols. If pigmented solution is dark additional $1 \mathrm{~mL}$ methanol may be added according to the situation to faint the color of the solution [38]. The mixture was centrifuged for $5 \mathrm{~min}$ at 5000 revolutions at $27{ }^{\circ} \mathrm{C}$ and repeated two times to obtain good results. The transparent supernatant layer of solvent was detected, collected by micro pipette and stored in glass bottles evaporated to dryness in fume hood. About $1 \mathrm{~mL}$ methanol dissolved into the dried samples and stored at $-4{ }^{\circ} \mathrm{C}$ for further analysis [38].

\section{Gas Chromatography-Mass Spectrometry (GC-MS) Analysis}

GC-MS investigation was done on (Agilent 6890-5973 N USA) gas chromatograph set with a HP1 slender section (model number TG-5MS) on $(30 \mathrm{~m} \times 250 \mu \mathrm{m} \times 0.25 \mu \mathrm{m})$ polydimethylsiloxane having interfaced (Hewlett Packard $5973 \mathrm{~N}$ ) mass. The underlying temperature was maintained at $70{ }^{\circ} \mathrm{C}$ for $2 \mathrm{~min}$ and then increased to $200{ }^{\circ} \mathrm{C}$ at rate of $10{ }^{\circ} \mathrm{C} \mathrm{min}^{-1}$; inlet temperature was set to $250{ }^{\circ} \mathrm{C}$ with split ratio of 10:1. MS quadruple pipe and warm aux temperatures were $150{ }^{\circ} \mathrm{C}$ and $285^{\circ} \mathrm{C}$, respectively. The 
Table 1 Physical properties of bait fermentation

\begin{tabular}{|c|c|c|c|c|c|}
\hline \multirow[t]{2}{*}{ Solvents extracts } & \multirow[t]{2}{*}{ Treatment } & \multicolumn{4}{|c|}{ Physical properties } \\
\hline & & Color & Opaqueness & Stickiness & Appearance \\
\hline Methanol & Sugar fermented bait & Dark brown & Shiny & Hard stone like & Immotile \\
\hline Distilled water & & Less dark brown & Dull/crystalline & Sticky & Motile \\
\hline
\end{tabular}

MS examine was 35-520 units and helium gas utilized as transporter with $1.0 \mathrm{~mL} \mathrm{~min}^{-1}$ stream rate. The relative yield of mixes crude information was determined depend on gas chromatography (GC) zones with a FID redress factor which is explicit, direct, delicate, exact and precise $[37,39]$ strategy for estimation.

\section{Statistical analysis}

The week-wise insect diversity collected and three times extracted bait yields analyzed statistically by one-way analysis of variance with Duncan's Multiple Range test keeping in view $P>0.05$. All the analysis for recorded data performed by SPSS statistical software (version 13.0; Inc., Chicago, IL, USA).

Co-efficient of determination $\left(R^{2}\right)$ carried out for the model comparison between means of first, second and third times extracted yields by polar solvents compared to root mean square error (RMSE). RMSE gave magnitude of the characteristic variation between predicted and observed data [40] resulted to assess the precision of the model [41].

\section{Results}

The study showed significant $(P<0.05)$ difference in last week of August, 2019 in treated (560 insects related to 11 families) and control traps (219 insects with 13 different families) (Fig. 2a). Insects (248 insects with 13 families) were recorded in treated traps were $24.70 \%$ more abundance than in control trap (189 insects with 13 families) during 1st week of September (Fig. 2b). Insects recorded in treated traps (567 different adult insects and 13 different families) were $68.43 \%$ more than in control in 2nd week of September (Fig. 2c). Insects in treated traps (315 number of different insects with 8 families) were $77.78 \%$ more than in control in 3rd week (Fig. 2d). Insects collected in treated traps (133 different types of insects with 8 families) were $54.89 \%$ more than in control recorded in last week of September (Fig. 2e). The insects were identified under microscope according to morph metric characteristics.

The calculated values of Shannon- Wiener's diversity index during 4th week of August recorded high (1.628) for Noctuidae family followed by Muscidae (1.437) in treated traps. Soybean pests yielded 0.368 in Tephritidae followed by Noctuidae (0.352). The results showed that insects of Lapidoptera, Diptera, Hymenoptera, Neuroptera attracted by the pharomonic activity of bait fermentation were well distributed both in control and treated traps. Maximum rank abundance and diversity of these pests were recorded in treated cage compared to control. Simpson's diversity index (1-D) ranged from 0.85 (Noctuidae) to 0.86 recorded maximum diversity in treated trap, while rest of the families recorded low or no diversity. Similarly, Muscidae (0.94), Noctuidae (0.95) and Tephritidae (0.97) were more diversified in control compared to rest of the treatments (Table 2(a)).

Margalef's index in treated trap was maximum (10.77) followed by control trap (8.09) in 1st week (Table 2(b)) followed by 8.48 and 6.09 in 2nd week (Table 2(c)), 7.12 and 2.68 in 3rd week (Table 2(d)) and 5.73 and 2.66 recorded in 4th week of September (Table 2(e)). Our results showed that maximum species richness (Margalef's index) was recorded in control (10.43) compared to treated (9.48) in 4th week of August (Table 2(a)). The yielded values of this index indicated that insects investigated in treated traps have more richness compared to control. Shannon's equitability's calculated that insect populations recorded high in Noctuidae (1.48) followed by Muscidae (1.31) in treated traps (Table 2(a)). It was observed clearly that the insects collected in treated traps recorded high equitability of the Noctuidae and Muscidae families in both treatments.

Similar eveness was recorded in Syrphidae (0.33), Formacidae (0.33) and Noctuidae (0.32) in treated traps (Table 2(b)). Maximum evenness was observed in Muscidae family (2.05) followed by Crysopidae (0.35) and Pieridae (0.31) in treated trap compared to other insects families during 2nd week of September (Table 2(c)). In 3rd week elevated evenness was recorded in Noctuidae (0.44) followed by Syrphidae (0.32) and Muscidae (0.29) in treated cages (Table 2(d)) compared to 4th week of September (Table 2(e)).

Furthermore the economic analysis of bait fermentation proved that it was eco-friendly, consumed only 0.64 RMB/0.09 USD per location, and did not spread toxic chemicals to the environment and surrounding area of human populations. 


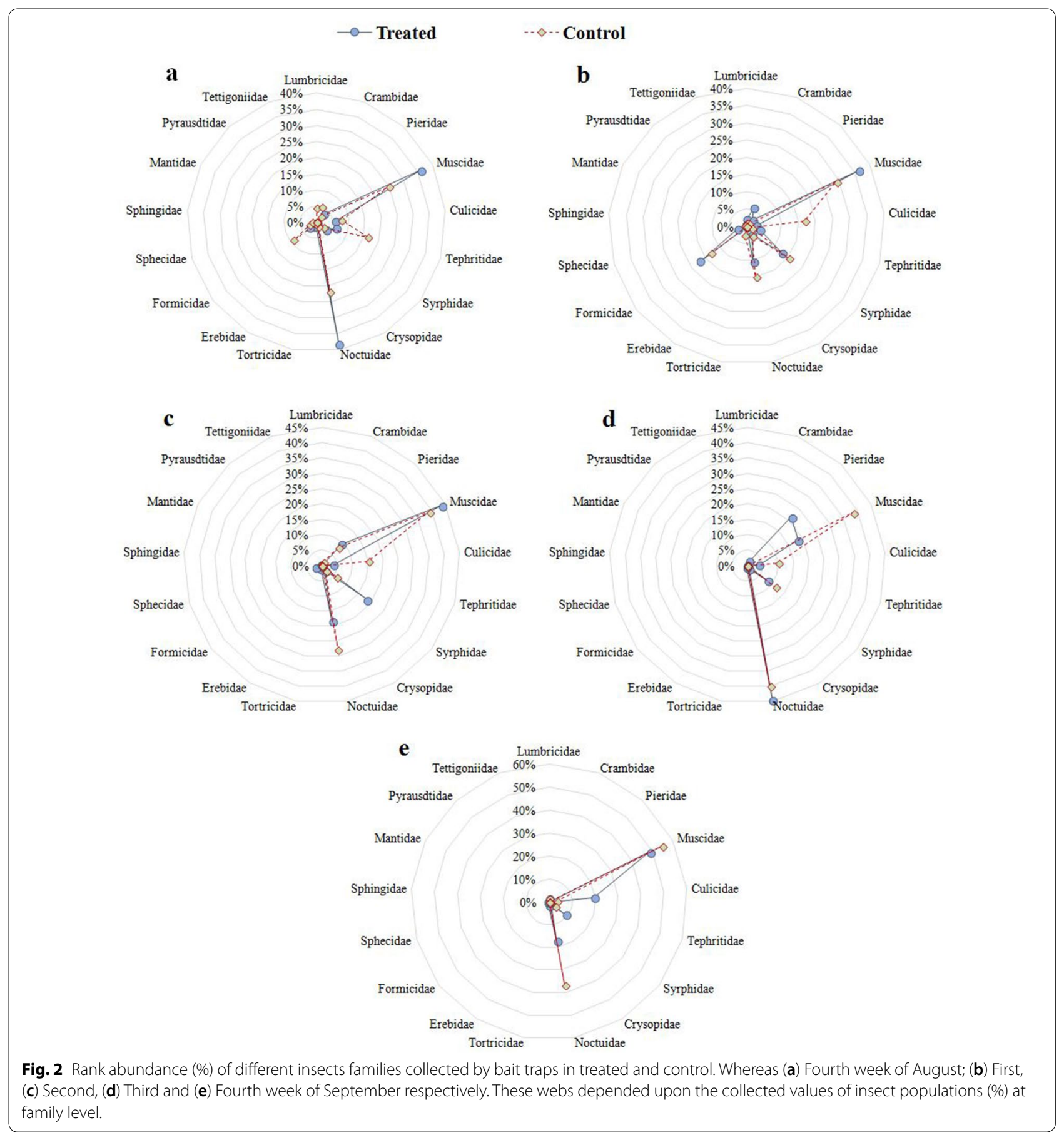

\section{Model validations}

The dry yield (g) recorded from each solvent extract showed significant $(\mathrm{P}<0.05)$ linear arc curve within treatments during first, second and third time extraction. Coefficient of determination recorded positive relationship by bait + methanol $\left(R^{2}=0.87\right.$ and $\left.\mathrm{RMSE}=0.97\right)$ extraction and materials extracted from bait + distilled water $\left(R^{2}=0.87\right.$ and RMSE $\left.=0.93\right)$ indicated better performance of the model fitness (Table 3).

\section{GC-MS screening bait fermentation}

The low polarity solvent (distilled water) was involved for the extraction of volatile compounds from bait fermentation through GC-MS analytical technique. The results of GC-MS showed that twenty-two different compounds 
Table 2 Rank of diversity indices of insect orders and different families collected from treated and control traps, (a) Forth week of August, (b) First week of September, (c) Second week of September, (d) Third week of September, (e) Forth week of September

\begin{tabular}{|c|c|c|c|c|c|c|c|c|}
\hline \multirow[t]{3}{*}{$\mathbf{R}$} & \multirow[t]{3}{*}{ Order } & \multirow[t]{3}{*}{ Insect families } & \multicolumn{6}{|c|}{ Diversity indices } \\
\hline & & & \multicolumn{3}{|c|}{ Treated } & \multicolumn{3}{|c|}{ Control } \\
\hline & & & Hs & SID & SE & Hs & SID & SE \\
\hline \multicolumn{9}{|l|}{ (a) 4th week } \\
\hline 1 & Lepidoptera & Noctuidae & 1.628 & 0.85 & 1.48 & 0.352 & 0.95 & 0.32 \\
\hline 2 & & Crambidae & 0 & 1 & 0 & 0.243 & 0.99 & 0.22 \\
\hline 3 & & Pieridae & 0.316 & 0.99 & 0.29 & 0.15 & 0.99 & 0.22 \\
\hline 4 & & Pyrausdtidae & 0 & 1 & 0 & 0 & 1 & 0 \\
\hline 5 & & Tortricidae & 0 & 0.99 & 0 & 0 & 1 & 0 \\
\hline 6 & & Erebidae & 0.202 & 0.999 & 0.18 & 0.046 & 1 & 0 \\
\hline 7 & & Sphingidae & 0.046 & 1 & 0 & 0.105 & 0.99 & 0.15 \\
\hline 8 & Diptera & Muscidae & 1.437 & 0.86 & 1.31 & 0.329 & 0.94 & 0.3 \\
\hline 9 & & Culicidae & 0.365 & 0.99 & 0.33 & 0.301 & 0.99 & 0.27 \\
\hline 10 & & Tephritidae & 0.368 & 0.99 & 0.33 & 0.368 & 0.97 & 0.33 \\
\hline 11 & & Syrphidae & 0.328 & 0.99 & 0.3 & 0.169 & 0.99 & 0.24 \\
\hline 12 & Hymenoptera & Formicidae & 0.275 & 0.99 & 0.25 & 0.316 & 0.99 & 0.29 \\
\hline 13 & & Sphecidae & 0.105 & 0.99 & 0 & 0.15 & 0.99 & 0.22 \\
\hline 14 & Neuroptera & Crysopidae & 0.129 & 0.99 & 0.19 & 0.105 & 0.99 & 0.1 \\
\hline 15 & & Lumbricidae & 0 & 1 & 0 & 0.23 & 0.99 & 0.21 \\
\hline 16 & Mantodea & Mantidae & 0 & 1 & 0 & 0 & 1 & 0 \\
\hline 17 & Orthoptera & Tettigoniidae & 0 & 1 & 0 & 0 & 1 & 0 \\
\hline \multirow[t]{4}{*}{ Species richness } & & $\mathrm{Ni}$ & 5.2 & 0.71 & 4.66 & 2.864 & 0.85 & 2.87 \\
\hline & & $\mathrm{N}$ & 9.67 & & & $\mathrm{~N}$ & 10.67 & \\
\hline & & $\mathrm{R}$ & 0.71 & Ev & & $\mathrm{R}$ & 1.24 & Ev \\
\hline & & $d$ & 9.48 & 0.41 & & $d$ & 10.43 & 1.21 \\
\hline \multicolumn{9}{|l|}{ (b) 1st week } \\
\hline 1 & Lepidoptera & Noctuidae & 0.35 & 0.99 & 0.32 & 0.356 & 0.98 & 0.32 \\
\hline 2 & & Crambidae & 0.275 & 0.99 & 0.25 & 0.078 & 0.99 & 0.11 \\
\hline 3 & & Pieridae & 0.169 & 0.99 & 0.15 & 0.078 & 0.99 & 0.11 \\
\hline 4 & & Pyrausdtidae & 0 & 1 & 0 & 0 & 1 & 0 \\
\hline 5 & & Tortricidae & 0 & 1 & 0 & 0 & 0.99 & 0 \\
\hline 6 & & Erebidae & 0 & 1 & 0 & 0 & 1 & 0 \\
\hline 7 & & Sphingidae & 0.046 & 1 & 0 & 0 & 1 & 0 \\
\hline 8 & Diptera & Muscidae & 0.095 & 0.87 & 0.09 & 0.329 & 0.92 & 0.3 \\
\hline 9 & & Culicidae & 0.186 & 0.99 & 0.17 & 0.365 & 0.97 & 0.33 \\
\hline 10 & & Tephritidae & 0.23 & 0.99 & 0.21 & 0.105 & 0.99 & 0 \\
\hline 11 & & Syrphidae & 0.365 & 0.98 & 0.33 & 0.359 & 0.97 & 0.33 \\
\hline 12 & Hymenoptera & Formicidae & 0.359 & 0.96 & 0.33 & 0.343 & 0.98 & 0.31 \\
\hline 13 & & Sphecidae & 0.186 & 0.99 & 0 & 0 & 1 & 0 \\
\hline 14 & Neuroptera & Crysopidae & 0.186 & 0.99 & 0.269 & 0.17 & 0.99 & 0.15 \\
\hline 15 & & Lumbricidae & 0.15 & 0.99 & 0.216 & 0.08 & 0.99 & 0.11 \\
\hline 16 & Mantodea & Mantidae & 0 & 1 & 0 & 0 & 1 & 0 \\
\hline 17 & Orthoptera & Tettigoniidae & 0 & 1 & 0 & 0 & 1 & 0 \\
\hline \multirow[t]{4}{*}{ Species richness } & & $\mathrm{Ni}$ & 2.598 & 0.81 & 2.5 & 2.26 & 0.83 & 2.08 \\
\hline & & $\mathrm{N}$ & 11 & & & N & 8.33 & \\
\hline & & R & 1.2 & & Ev & R & 1.05 & Ev \\
\hline & & $d$ & 10.77 & & 1.084 & $d$ & 8.09 & 1.07 \\
\hline
\end{tabular}


Table 2 (continued)

\begin{tabular}{|c|c|c|c|c|c|c|c|c|}
\hline \multicolumn{9}{|l|}{ (c) 2nd week } \\
\hline 1 & Lepidoptera & Noctuidae & 0.0408 & 0.97 & 0.04 & 0.347 & 0.92 & 0.32 \\
\hline 2 & & Crambidae & 0 & 1 & 0 & 0.078 & 0.99 & 0 \\
\hline 3 & & Pieridae & 0.336 & 0.99 & 0.31 & 0.275 & 0.99 & 0.25 \\
\hline 4 & & Pyrausdtidae & 0 & 0.99 & 0 & 0 & 1 & 0 \\
\hline 5 & & Tortricidae & 0 & 0.99 & 0 & 0 & 1 & 0 \\
\hline 6 & & Erebidae & 0.078 & 0.99 & 0.07 & 0 & 1 & 0 \\
\hline 7 & & Sphingidae & 0 & 1 & 0 & 0 & 1 & 0 \\
\hline 8 & Diptera & Muscidae & 2.2525 & 0.81 & 2.05 & 0.25 & 0.84 & 0.23 \\
\hline 9 & & Culicidae & 0.328 & 0.99 & 0.3 & 0.354 & 0.98 & 0.32 \\
\hline 10 & & Tephritidae & 0 & 1 & 0 & 0 & 1 & 0 \\
\hline 11 & & Syrphidae & 0.0512 & 0.96 & 0.05 & 0.243 & 0.99 & 0.35 \\
\hline 12 & Hymenoptera & Formicidae & 0 & 1 & 0 & 0 & 1 & 0 \\
\hline 13 & & Sphecidae & 0.243 & 0.99 & 0.22 & 0 & 1 & 0 \\
\hline 14 & Neuroptera & Crysopidae & 0.243 & 0.99 & 0.35 & 0.129 & 0.99 & 0.12 \\
\hline 15 & & Lumbricidae & 0.078 & 0.99 & 0 & 0.046 & 1 & 0 \\
\hline 16 & Mantodea & Mantidae & 0 & 1 & 0 & 0 & 1 & 0 \\
\hline 17 & Orthoptera & Tettigoniidae & 0 & 1 & 0 & 0 & 1 & 0 \\
\hline \multirow[t]{4}{*}{ Species richness } & & $\mathrm{Ni}$ & 1.0382 & 0.73 & 1.77 & 1.721 & 0.78 & 3.17 \\
\hline & & $\mathrm{N}$ & 8.67 & & & $\mathrm{~N}$ & 6.33 & \\
\hline & & $\mathrm{R}$ & 0.63 & Ev & & $\mathrm{R}$ & 0.82 & Ev \\
\hline & & $d$ & 8.48 & 0.4818 & & $d$ & 6.09 & 0.93 \\
\hline \multicolumn{9}{|l|}{ (d) 3rd week } \\
\hline 1 & Lepidoptera & Noctuidae & 0.4845 & 0.80 & 0.44 & 0.356 & 0.84 & 0.32 \\
\hline 2 & & Crambidae & 0.15 & 0.99 & 0.14 & 0 & 1 & 0 \\
\hline 3 & & Pieridae & 0.268 & 0.95 & 0.24 & 0 & 1 & 0 \\
\hline 4 & & Pyrausdtidae & 0 & 1 & 0 & 0 & 1 & 0 \\
\hline 5 & & Tortricidae & 0.078 & 0.99 & 0.11 & 0 & 1 & 0 \\
\hline 6 & & Erebidae & 0 & 1 & 0 & 0 & 1 & 0 \\
\hline 7 & & Sphingidae & 0 & 1 & 0 & 0 & 1 & 0 \\
\hline 8 & Diptera & Muscidae & 0.316 & 0.96 & 0.29 & 0.354 & 0.85 & 0.32 \\
\hline 9 & & Culicidae & 0.254 & 0.99 & 0.23 & 0.186 & 0.99 & 0 \\
\hline 10 & & Tephritidae & 0 & 1 & 0 & 0 & 1 & 0 \\
\hline 11 & & Syrphidae & 0.35 & 0.99 & 0.32 & 0.202 & 0.99 & 0.29 \\
\hline 12 & Hymenoptera & Formicidae & 0 & 1 & 0 & 0 & 1 & 0 \\
\hline 13 & & Sphecidae & 0 & 1 & 0 & 0 & 1 & 0 \\
\hline 14 & Neuroptera & Crysopidae & 0.129 & 0.99 & 0.19 & 0 & 1 & 0 \\
\hline 15 & & Lumbricidae & 0 & 1 & 0 & 0 & 1 & 0 \\
\hline 16 & Mantodea & Mantidae & 0 & 1 & 0 & 0 & 1 & 0 \\
\hline 17 & Orthoptera & Tettigoniidae & 0 & 1 & 0 & 0 & 1 & 0 \\
\hline \multirow[t]{4}{*}{ Species richness } & & $\mathrm{Ni}$ & 1.061 & 0.71 & 2.15 & 1.098 & 0.68 & 1.87 \\
\hline & & $\mathrm{N}$ & 7.333 & & & N & 3 & \\
\hline & & $\mathrm{R}$ & 0.72 & Ev & & $\mathrm{R}$ & 0.63 & Ev \\
\hline & & $d$ & 7.12 & 0.5321 & & $d$ & 2.68 & 1 \\
\hline
\end{tabular}


Table 2 (continued)

\begin{tabular}{|c|c|c|c|c|c|c|c|c|}
\hline \multicolumn{9}{|l|}{ (e) 4th week } \\
\hline 1 & Lepidoptera & Noctuidae & 0.338 & 0.97 & 0.31 & 0.333 & 0.87 & 0.3 \\
\hline 2 & & Crambidae & 0 & 1 & 0 & 0 & 1 & 0 \\
\hline 3 & & Pieridae & 0 & 1 & 0 & 0 & 1 & 0 \\
\hline 4 & & Pyrausdtidae & 0 & 1 & 0 & 0 & 1 & 0 \\
\hline 5 & & Tortricidae & 0.078 & 0.99 & 0.11 & 0 & 1 & 0 \\
\hline 6 & & Erebidae & 0 & 1 & 0 & 0 & 1 & 0 \\
\hline 7 & & Sphingidae & 0.046 & 1 & 0 & 0 & 1 & 0 \\
\hline 8 & Diptera & Muscidae & 0.28 & 0.76 & 0.25 & 0.366 & 0.7 & 0.33 \\
\hline 9 & & Culicidae & 0.35 & 0.96 & 0.32 & 0.078 & 0.99 & 0 \\
\hline 10 & & Tephritidae & 0 & 1 & 0 & 0 & 1 & 0 \\
\hline 11 & & Syrphidae & 0.254 & 0.99 & 0.23 & 0.078 & 0.99 & 0 \\
\hline 12 & Hymenoptera & Formicidae & 0 & & 0 & 0 & 1 & 0 \\
\hline 13 & & Sphecidae & 0 & 1 & 0 & 0 & 1 & 0 \\
\hline 14 & Neuroptera & Crysopidae & 0.078 & 0.99 & 0 & 0 & 1 & 0 \\
\hline 15 & & Lumbricidae & 0.078 & 0.99 & 0.11 & 0.046 & 1 & 0 \\
\hline 16 & Mantodea & Mantidae & 0 & 1 & 0 & 0 & 1 & 0 \\
\hline 17 & Orthoptera & Tettigoniidae & 0 & 1 & 0 & 0 & 1 & 0 \\
\hline \multirow[t]{4}{*}{ Species richness } & & $\mathrm{Ni}$ & 1.503 & 0.69 & 1.34 & 0.901 & 0.57 & 0.63 \\
\hline & & $\mathrm{N}$ & 6 & & & N & 3 & \\
\hline & & $\mathrm{R}$ & 0.9 & $\mathrm{Ev}$ & & R & 0.68 & Ev \\
\hline & & $d$ & 5.73 & 0.84 & & $d$ & 2.66 & 0.82 \\
\hline
\end{tabular}

$R$ Rank, Hs Shannon-Weiner index, SID Simpson Index of Diversity, SE Species Equitability, Ni number of individuals, $N$ number of families, $R$ Menhenick index, Ev evenness, $d$ Margalef's Index

were detected at different retention times (RT) with 99.99\% correspondence of bioactive compounds. Similarly the high polarity solvent (methanol) was also checked for compounds determination. Twenty-two different bioactive compounds were detected (Table 4).

\section{Discussion}

The present investigations recorded diversity indices of seventeen insect's families with in six orders collected in treated traps suggested significant $(\mathrm{P}<0.05)$ abundance ranged $24.70-77.78 \%$. These results are in agreement with the scientists who reported that the insect populations of Noctuidae, Pieridae, Lycaenidae, Nymphalidae, Hesperiidae families increased by sugar fermented traps [30, 67, 68]. Our results suggested that the height of webs (Fig. 2) depended upon the collected values of insect populations at family level. High value of ShannonWiener's diversity index recorded in Noctuidae followed by Muscidae. These investigations are in accordance to the researchers who described higher Shannon index value $(P<0.01)$ in their experiments [69]. Our investigations suggested significant $(\mathrm{P}<0.05)$ soybean pest yielded high in Tephritidae during last week of August are in accordance to the researchers reported similar recommendations [70]. Margalef's index recorded maximum in treated trap followed by control in 1st week of September.
The insects yielded with Shannon's equitability's investigated high value in Noctuidae compared to Muscidae in treated traps. Maximum evenness recorded in Muscidae are in line with the researchers who revealed species uniformity or evenness of cabbage pests [69]. Our results are in agreement with the researchers who reported that fermented bait is successful biocontrol agent to attract the major and minor pests [71-74]. Lepidopterous moth attracted by the pharomonic activity of fruits fermented baits for collecting their protein food and trapped easily $[75,76]$. The moths of different families were attracted to baits traps may give reliable estimates of captured moth diversity [77].

Our hypothesis was confirmed that insect diversity of different families is high and first time dry mass yield (g) extracted from different polar solvents recorded significant $(\mathrm{P}<0.05)$ results compared to rest of extractions. According to the literature cited, our traditionally prepared bait fermentation contained bioactive compounds, which attract the respective insects and charged only 0.64 RMB or 0.09 USD per location. The bait fermentation is cheap, economical and easy to install source for the attraction of insects in current scenario. The different polarity solvents of bait fermentation were analyzed through GC-MS analytical technique and showed that twenty-two different types of bioactive compounds were 
Table 3 Coefficient of determination $\left(R^{2}\right)$ showing the relationship between low and high polarity extraction solvent on yield ( $g$ ) and root mean square error (RMSE) of bait fermentation

\begin{tabular}{lllllll}
\hline Treatments & \multicolumn{2}{l}{ Extraction yield $(\mathbf{g})$} & & Regression Equation & $\boldsymbol{R}^{\mathbf{2}}$ & \\
\cline { 2 - 5 } & First & Second & Third & & \\
\hline Bait + distilled water & $0.9579 \mathrm{a}$ & $0.2208 \mathrm{~b}$ & $0.0705 \mathrm{c}$ & $-0.4437 x+1.3038$ & 0.87 \\
Bait + methanol & $0.9071 \mathrm{a}$ & $0.2417 \mathrm{~b}$ & $0.1115 \mathrm{c}$ & $-0.3978 \mathrm{x}+1.2157$ & 0.97 \\
\hline
\end{tabular}

Whereas level of significance was $P=0.05, R M S E$ root mean square error, $R^{2}$ Coefficient of determination

Table 4 Chemical composition of bait fermentation with different solvents by GC-MS

\begin{tabular}{|c|c|c|c|c|c|c|c|c|}
\hline \multicolumn{4}{|c|}{ Distilled water extract } & \multicolumn{4}{|c|}{ Methanol extract } & \multirow[t]{2}{*}{ Refs. } \\
\hline RT & Chemical name & M.F. & MM & RT & Chemical name & M.F. & MM & \\
\hline 3.23 & p-Xylene & $\mathrm{C}_{8} \mathrm{H}_{10}$ & 106 & 3.23 & p-Xylol & $\mathrm{C}_{8} \mathrm{H}_{10}$ & 106 & NC \\
\hline 3.83 & $N$-Methyl- $\beta$-phenethylamine & $\mathrm{C}_{9} \mathrm{H}_{13} \mathrm{~N}$ & 135 & 3.83 & Carboxyacetic acid & $\mathrm{C}_{3} \mathrm{H}_{4} \mathrm{O}_{4}$ & 104 & {$[42-44]$} \\
\hline 3.93 & Hemimellitene & $\mathrm{C}_{9} \mathrm{H}_{12}$ & 120 & 3.92 & Rubeanic acid & $\mathrm{C}_{2} \mathrm{H}_{4} \mathrm{~N}_{2} \mathrm{~S}_{2}$ & 120 & $N C,[45]$ \\
\hline 4.01 & Pseudocumo & $\mathrm{C}_{9} \mathrm{H}_{12}$ & 120 & 4.00 & Nitrosomethylurea & $\mathrm{C}_{2} \mathrm{H}_{5} \mathrm{~N}_{3} \mathrm{O}_{2}$ & 103 & $N C,[46]$ \\
\hline 4.09 & Octamethylcyclotetrasiloxane & $\mathrm{C}_{8} \mathrm{H}_{24} \mathrm{O}_{4} \mathrm{Si}_{4}$ & 296 & 4.08 & Octamethyltetrasiloxane & $\mathrm{C}_{8} \mathrm{H}_{24} \mathrm{O}_{4} \mathrm{Si}_{4}$ & 296 & NC \\
\hline 4.15 & Methoxyphenamine, $\mathrm{N}$-desmethyl & $\mathrm{C}_{10} \mathrm{H}_{15} \mathrm{NO}$ & 165 & 4.13 & Nitrosomethylurea & $\mathrm{C}_{2} \mathrm{H}_{5} \mathrm{~N}_{3} \mathrm{O}_{2}$ & 103 & {$[46]$} \\
\hline 4.32 & Trimethylbenzene & $\mathrm{C}_{9} \mathrm{H}_{12}$ & 120 & 4.30 & 1-Aminoglycerol & $\mathrm{C}_{3} \mathrm{H}_{9} \mathrm{NO}_{2}$ & 91 & $N C,[47-51]$ \\
\hline 4.88 & Allylbenzene & $\mathrm{C}_{9} \mathrm{H}_{10}$ & 118 & 4.87 & Benzocyclopentane & $\mathrm{C}_{9} \mathrm{H}_{10}$ & 118 & NC \\
\hline 5.53 & Hendecane & $\mathrm{C}_{11} \mathrm{H}_{24}$ & 156 & 5.52 & 2-Methylpiperazine & $\mathrm{C}_{5} \mathrm{H}_{12} \mathrm{~N}_{2}$ & 100 & {$[52]$} \\
\hline 5.60 & 1,2:7,8-Dibenzocarbazole & $\mathrm{C}_{20} \mathrm{H}_{13} \mathrm{~N}$ & 267 & 5.64 & Glyoxylic acid & $\mathrm{C}_{2} \mathrm{H}_{2} \mathrm{O}_{3}$ & 74 & {$[53,54]$} \\
\hline 5.65 & Dexamphetamine & $\mathrm{C}_{9} \mathrm{H}_{13} \mathrm{~N}$ & 135 & 6.40 & 3,4-Furandiol, tetrahydro-, trans- & $\mathrm{C}_{4} \mathrm{H}_{8} \mathrm{O}_{3}$ & 104 & [45] \\
\hline 6.42 & Dexamphetamine & $\mathrm{C}_{9} \mathrm{H}_{13} \mathrm{~N}$ & 135 & 6.57 & Tetralin & $\mathrm{C}_{10} \mathrm{H}_{12}$ & 132 & {$[45,55]$} \\
\hline 6.59 & Naphthalene-1,2,3,4-tetrahydride & $\mathrm{C}_{10} \mathrm{H}_{12}$ & 132 & 6.95 & Camphor tar & $\mathrm{C}_{10} \mathrm{H}_{8}$ & 128 & NC \\
\hline 7.32 & Dexamphetamine & $\mathrm{C}_{9} \mathrm{H}_{13} \mathrm{~N}$ & 135 & 7.31 & Tetraacetyl-d-xylonic nitrile & $\mathrm{C}_{14} \mathrm{H}_{17} \mathrm{NO}_{9}$ & 343 & {$[45]$} \\
\hline 7.48 & Dexamphetamine & $\mathrm{C}_{9} \mathrm{H}_{13} \mathrm{~N}$ & 135 & 7.47 & o-Methylisourea hydrogen sulfate & $\mathrm{C}_{2} \mathrm{H}_{8} \mathrm{~N}_{2} \mathrm{O}_{5} \mathrm{~S}$ & 172 & {$[45,56]$} \\
\hline 9.37 & Fluoroacetamide & $\mathrm{C}_{2} \mathrm{H}_{4} \mathrm{FNO}$ & 77 & 7.99 & 1,4-Anhydro-I-threitol & $\mathrm{C}_{4} \mathrm{H}_{8} \mathrm{O}_{3}$ & 104 & [57] \\
\hline 9.53 & $\begin{array}{l}\text { 5-[4-(Dimethylamino)cinnamoyl] } \\
\text { acenaphthene }\end{array}$ & $\mathrm{C}_{23} \mathrm{H}_{21} \mathrm{NO}$ & 327 & 9.52 & L-Cysteine disulfide & $\mathrm{C}_{6} \mathrm{H}_{12} \mathrm{~N}_{2} \mathrm{O}_{4} \mathrm{~S}_{2}$ & 240 & {$[47,58]$} \\
\hline 11.1 & 2-Aminoundecane & $\mathrm{C}_{11} \mathrm{H}_{25} \mathrm{~N}$ & 171 & 9.72 & Tetraacetyl-d-xylonic nitrile & $\mathrm{C}_{14} \mathrm{H}_{17} \mathrm{NO}_{9}$ & 343 & {$[59,60]$} \\
\hline 11.5 & Propionic acid amide & $\mathrm{C}_{3} \mathrm{H}_{7} \mathrm{NO}$ & 73 & 11.13 & N-Propylacetamide & $\mathrm{C}_{5} \mathrm{H}_{11} \mathrm{NO}$ & 101 & [61] \\
\hline 13.3 & L-Alanine-4-nitroanilide & $\mathrm{C}_{9} \mathrm{H}_{11} \mathrm{~N}_{3} \mathrm{O}_{3}$ & 209 & 11.50 & 1,3,5-Trioxacycloheptane & $\mathrm{C}_{4} \mathrm{H}_{8} \mathrm{O}_{3}$ & 104 & {$[62]$} \\
\hline 14.3 & 1,5-Diphenyl-2H-1,2,4-triazoline-3-thione & $\mathrm{C}_{14} \mathrm{H}_{11} \mathrm{~N}_{3} \mathrm{~S}$ & 253 & 13.37 & L-Cysteine disulfide & $\mathrm{C}_{6} \mathrm{H}_{12} \mathrm{~N}_{2} \mathrm{O}_{4} \mathrm{~S}_{2}$ & 240 & {$[63,64]$} \\
\hline 15.8 & 1,2-Dimethylpropylamine & $\mathrm{C}_{5} \mathrm{H}_{13} \mathrm{~N}$ & 87 & 14.29 & 1,5-Diphenyl-2H-1,2,4-triazoline-3-thione & $\mathrm{C}_{14} \mathrm{H}_{11} \mathrm{~N}_{3} \mathrm{~S}$ & 253 & {$[65,66]$} \\
\hline
\end{tabular}

$R T$ Retention time, $M . F$ molecular formula, $M M(\mathrm{~g} / \mathrm{mol})$ molar mass gram $/ \mathrm{mole}$, Refs. references, $N C$ non-target compound)

identified in both cases. Other researchers also reported that fermented bait could be used as attractant for Noctuidae insects [78-81]. Male and female flies feed on nectar and organic matter, so they are commonly attracted to waste receptacles and other forms of organic matter [82]. The researchers reported that metabolites release volatile fumes into the environment that convey specific message helpful for the attraction of different kinds of insects [34]. The researchers showed that fruit baits are necessary items in food ingredients for the attraction of tephritidae [83-85]. Many insects of order Diptera, Lapidoptera,
Hymenoptera and Neuroptera are attracted towards protein foods in bait trap, which are in line with the researchers who also reported that insects are attracted through chemicals signaling of organic compounds [31, 86]. This bait fermentation is cheap, non-toxic, safe and environment friendly due to their natural origin. In our study, we utilized typical beer, which gave satisfactory results according to the scientists who reported that lighter beer also attract the insects tremendously $[87,88]$. This bait is cost-effective, economical, safe used for Integrated Pest Management (IPM) [77]. 


\section{Conclusions}

Insects belonging to Lapidoptera, Diptera and other orders are attracted by the pharomones activity of bait fermentation, which undicates that major and minor pests and domestic insects (mosquito, house flies) are easily trapped. The bait treated trap captured the maximum abundance of insects populations compared to control and yielded higher diversity values. The fermented volatile organic compounds in bait attracted the insects. Both male and female insects were attracted successfully in bait traps, which play a vital role in Integrated Pest Management (IPM). Entomologists, ecologists and researchers are advised to innovate bait formulations for the use of broad spectrum field experiments and incearse the trapping efficiency of the insects. Additional investigations would be conducted on the chemical ecology of the target insect-pests and bait fermentation along with their interaction mechanism through olfactory responses of insects in future.

\section{Abbreviations}

GC-MS: Gas Chromatography and Mass Spectrometry; R²: Co-efficient of determination; RMB: Renminbi; USD: United States Dollar; ${ }^{\circ} \mathrm{N}$ : Degree North; 'E: Degree East; pH: Power of hydrogen ion; HPLC: High Performance Liquid Chromatography; GCB: Graphitized carbon black; $\mu$ m: Micrometer; FID: Flame ionization detector; R: Rank; Hs: Shannon-Weiner index; SID: Simpson index of diversity; SE: Species equitability; Ni: Number of individuals; N: Number of families; R: Menhenick index; Ev: Evenness; d: Margalef's Index; RMSE: Root mean square error; RT: Retention times; Refs: References; IPM: Integrated pest management.
\end{abstract}

\section{Acknowledgements}

The author would like to acknowledge the support of some laboratory fellows and thanks to the staff of College of Bioscience and Biotechnology, Shenyang Agricultural University, Shenyang, Liaoning, China. The authors are also thankful to three anonymous reviewers who were involved for the review process and English language editing of this manuscript.

\section{Authors' contributions}

YLF gave the concept of the experiments, MFI designed and performed all field, laboratory works like data collection, preparation of fermentations and extractions. YLF and MFI contributed with experimental work, statistical analysis, helped to write the manuscript. YLF was the chief organizer of this experimental research and coordinated with experimental activities. All the authors read critically and approved the final version of the manuscript. All authors read and approved the final manuscript.

\section{Funding}

The present study conducted with the support of National Key R\&D Program of China (2017YFC1200101), the National Natural Science Foundation of China (31670545 and 31971557). There is no role of the funding agency in the design of the study, collection, analysis, interpretation of data and in writing the manuscript.

\section{Availability of data and materials}

All the data of the study are included in this manuscript; hence there are no additional data with the authors.

\section{Ethics approval and consent to participate}

The insect's specimens collected during the field experiment in accordance to the international guidelines. Not applicable.

\section{Consent for publication}

Not applicable.

\section{Competing interests}

The authors declare that they have no competing interests.

\section{Author details}

${ }^{1}$ Liaoning Key Laboratory for Biological Invasions and Global Changes, College of Bioscience and Biotechnology, Shenyang Agricultural University, Shenyang 110866, Liaoning Province, People's Republic of China. ${ }^{2}$ Adaptive Research, Gujranwala 52330, Punjab Province, Pakistan.

Received: 18 February 2020 Accepted: 21 July 2020

Published online: 09 August 2020

\section{References}

1. Gupta RC (2019) Biomarkers in toxicology. Academic Press, San Diego

2. Goftishu M, Assefa Y, Niba A, Fininsa C, Le Ru BP (2018) Diversity and abundance of lepidopteran stem borers and their host plants in Ethiopia. J Appl Entomol 142(4):437-449

3. Guo J, Fu X, Zhao S, Shen X, Wyckhuys KAG, Wu K (2020) Long-term shifts in abundance of (migratory) crop-feeding and beneficial insect species in northeastern Asia. J Pest Sci 93:583-594. https://doi.org/10.1007/s1034 0-019-01191-9

4. Lippmann M, Leikauf GD (2020) Environmental toxicants: human exposures and their health effects. Wiley, New York

5. Bempah CK, Asomaning J, Boateng J (2020) Market basket survey for some pesticides residues in fruits and vegetables from Ghana. J Microbiol Biotechnol Food Sci 9(4):850-871

6. Sapbamrer R, Thongtip S, Khacha-ananda S, Sittitoon N, Wunnapuk K (2020) Changes in lung function and respiratory symptoms during pesticide spraying season among male sprayers. Arch Environ Occup Health 75(2):88-97

7. Bao W, Liu B, Simonsen DW, Lehmler H-J (2020) Association between exposure to pyrethroid insecticides and risk of all-cause and causespecific mortality in the general US adult population. JAMA Intern Med 180(3):367-374

8. Pang AM, Gay S, Yadav R, Dolea C, Ponce C, Velayudhan R, Grout A, Fehr J, Plenge-Boenig A, Schlagenhauf P (2020) The safety and applicability of synthetic pyrethroid insecticides for aircraft disinsection: a systematic review. Travel Med Infect Dis 33:101570

9. Spiewak R (2020) Farmers and farmworkers. In: John S, Johansen J, Rustemeyer T, Elsner P, Maibach H (eds) Kanerva's occupational dermatology. Springer, Cham, pp 1929-1946. https://doi.org/10.1007/978-3-319-68617 $-2 \_150$

10. Manna B, MaitiDutta S, Dalapati S, Maiti S (2020) Oxidative stress induced toxicity and DNA stability in some agri-field based livestock/insect by widely used pesticides. Comb Chem High Throughput Screening. https:// doi.org/10.2174/1386207323666200415110745

11. Wise K, Cummings J, English K (2018) Dairy and beef cattle fly IPM Training videos: an integrated pest management program for New York State, 2017-2020 USDA-NIFA CPPM

12. Ahmed M, Peiwen Q, Gu Z, Liu Y, Sikandar A, Hussain D, Javeed A, Shafi J, lqbal MF, An R (2020) Insecticidal activity and biochemical composition of Citrullus colocynthis, Cannabis indica and Artemisia argyi extracts against cabbage aphid (Brevicoryne brassicae L). Sci Rep 10(1):1-10

13. Jeyasankar A (2017) Phytochemicals: as alternate to chemical pesticides for insects pest management. Microbiol Rev 12(4):564-582

14. Lamara R, Andama M, Olet EA (2020) Phytochemical composition of aqueous crude extracts of selected pesticidal plants used against brassica vegetable pests. Int J Curr Microbiol App Sci 9(1):468-478

15. Damalas CA, Koutroubas SD (2020) Botanical Pesticides for eco-friendly pest management: drawbacks and limitations. Pesticides Crop Prod Physiol Biochem Action. https://doi.org/10.1002/9781119432241.ch10

16. Saroj A, Oriyomi OV, Nayak AK, Haider SZ (2020) Phytochemicals of plantderived essential oils: A novel green approach against pests. In: Egbuna C, Sawicka B (eds) Natural remedies for pest, disease and weed control. Elsevier, Amsterdam, pp 65-79. https://doi.org/10.1016/B978-0-12-81930 4-4.00006-3 
17. Riat AK (2019) Consequences of phytochemicals on the system of various pest: a review. Res J Pharm Technol 12(9):4595-4598

18. Jaoko V, Nji Tizi Taning C, Backx S, Mulatya J, Van den Abeele J, Magomere T, Olubayo F, Mangelinckx S, Werbrouck SPO, Smagghe G (2020) The phytochemical composition of Melia volkensii and its potential for insect pest management. Plants 9(2):143

19. Oriyomi OV (2018) Phytochemical biopesticides. In: Phytochemistry. edn.: Apple Academic Press, pp 303-324

20. Iqbal MF, Hussain M, Ali MA, Waqar MQ, Nawaz R (2013) Insecticidal activity of different herbal extracts against aphid in bread wheat. Int J Agric Appl Sci (Pakistan) 5(2):98-101

21. Iqbal MF, Kahloon MH, Nawaz MR, Javaid MI (2011) Effectiveness of some botanical extracts on wheat aphids. J Anim Plant Sci 21(1):114-115

22. Iqbal MF, Feng WW, Guan M, Xiang LZ, Feng YL (2020) Biological control of natural herbivores on Ambrosia species at Liaoning Province in Northeast China. Appl Ecol Environ Res 18(1):1419-1436

23. Landolt PJ (1995) Attraction of Mocis latipes (Lepidoptera: Noctuidae) to sweet baits in traps. Florida Entomol 78(3):523

24. Utrio P, Eriksson K (1977) Volatile fermentation products as attractants for Macrolepidoptera. Ann Zool Fenn 14(2):98-104

25. Suckling DM, Thomas WP, Burnip GM, Robson A (1990) Monitoring lepidopterous pests at two Canterbury orchards. In: Proceedings of the forty third new zealand weed and pest control conference, pp 322-327. https ://doi.org/10.30843/nzpp.1990.43.10916

26. Butenandt A, Beckmann R, Stamm D, Hevker E (1959) On the sex pheromone of the silkworm moth Bombyx mori, isolation and structure. $Z$ Naturforsch B 14:283-284

27. El-Sayed AM (2008) The pherobase: database of insect pheromones and semiochemicals. http://www.pherobase.com

28. I I bal MF, Feng YL, Liu MC, Lu XR, Nasir M, Sikandar A (2019) Parasitic activity of powdery mildew (pathogen strain HMLAC226) on prostrate knotweed (Polygonum aviculare l.) at various locations of shenyang, northeast china. Appl Ecol Environ Res 17(6):13383-13394

29. Kyerematen R, Owusu E, Acquah-Lamptey D, Anderson R, Ntiamoa-Baidu Y (2014) Species Composition and Diversity of Insects of the Kogyae Strict Nature Reserve in Ghana. Open J Ecol 4(17):1061-1079

30. Laaksonen J, Laaksonen T, Itamies J, Rytkonen S, Valimaki P (2006) A new efficient bait-trap model for Lepidoptera surveys-the" Oulu" model. Entomologica Fennica 17(2):153

31. Pettersson LB, Franzén M (2008) Comparing wine-based and beer-based baits for moth trapping: a field experiment. Entomologisk Tidskrift 129(3):129-134

32. Shannon ER, Wiener W (1963) The mathematical theory of communication University of Illinois press Urbana Illinois, pp 117

33. Simpson EH (1949) Measurement of diversity. Nature 163(4148):688

34. Margalef R (1969) Diversity and stability: a practical proposal and a model of interdependence. Brookhaven Symp Biol 22:25-37. https://hdl.handl e.net/10261/166352

35. Nakamura H (1999) A method for environmental evaluation using indicator groups of butterflies and the Rl-index. Jpn J Environ Entomol Zool 10(4):143-159

36. Janković M, Miličić M, Nedeljković Z, Milovac Ž, Ačanski J, Vujić A (2019) Diversity and structure of hoverfly (Diptera: Syrphidae) communities in agricultural areas in Vojvodina Province (Serbia) a case study on Brassica napus L. J Entomol Res Soc 21(2):129-144

37. Ahmed M, Ji M, Sikandar A, Iram A, Qin P, Zhu H, Javeed A, Shafi J, lqbal Z, Farid lqbal M (2019) Phytochemical analysis, biochemical and mineral composition and GC-MS profiling of methanolic extract of Chinese arrowhead Sagittaria trifolia L. from Northeast China. Molecules 24(17):3025

38. Huang Z-h, Wang Z-I, Shi B-I, Wei D, Chen J-x, Wang S-I, Gao B-j (2015) Simultaneous determination of salicylic acid, jasmonic acid, methyl salicylate, and methyl jasmonate from UImus pumila leaves by GC-MS. Int J Anal Chem 2015: 698630. https://doi.org/10.1155/2015/698630

39. Tang L, Kim A, Miller SA, Lloyd DK (2010) Development and validation of a specific and sensitive GC-FID method for the determination of impurities in 5-chlorovaleroyl chloride. J Pharm Biomed Anal 53(3):309-314

40. Mayer DG, Butler DG (1993) Statistical validation. Ecol Model 68(1-2):21-32
41. Royo-Esnal A, Torra J, Conesa JA, Forcella F, Recasens J (2010) Modeling the emergence of three arable bedstraw (Galium) species. Weed Sci 58(1):10-15

42. El-Sayed AM, Heppelthwaite VJ, Manning LM, Gibb AR, Suckling DM (2005) Volatile constituents of fermented sugar baits and their attraction to lepidopteran species. J Agric Food Chem 53(4):953-958

43. Landolt PJ (2000) Chemical attractants for yellowjackets and paper wasps. In.: Google Patents

44. Gertler S, Steiner L, Mitchell W, Barthel W (1958) Insect attractants, esters of 6-methyl-3-cycohexene-1-carboxylic acid as attractants for the mediterranean fruit fly. J Agric Food Chem 6(8):592-594

45. Simchoni-Barak M, Schlein Y, Muller GC (2013) Controlling sugar feeding insects. In.: Google Patents

46. Bernier UR, Kline DL, Barnard DR, Schreck CE, Yost RA (2000) Analysis of human skin emanations by gas chromatography/mass spectrometry. 2 . Identification of volatile compounds that are candidate attractants for the yellow fever mosquito (Aedes aegypti). Anal Chem 72(4):747-756

47. Becher PG, Hagman A, Verschut V, Chakraborty A, Rozpędowska E, Lebreton S, Bengtsson M, Flick G, Witzgall P, Piškur J (2018) Chemical signaling and insect attraction is a conserved trait in yeasts. Ecol Evol 8(5):2962-2974

48. Bharathi TE, Sathiyanandam VK, David PMM (2004) Attractiveness of some food baits to the melon fruit fly, Bactrocera cucurbitae (Coquillett)(Diptera: Tephritidae). Int J Trop Insect Sci 24(2):125-134

49. Mazzetto F, Gonella E, Crotti E, Vacchini V, Syrpas M, Pontini M, Mangelinckx S, Daffonchio D, Alma A (2016) Olfactory attraction of Drosophila suzukii by symbiotic acetic acid bacteria. J Pest Sci 89(3):783-792

50. Hamby KA, Becher PG (2016) Current knowledge of interactions between Drosophila suzukii and microbes, and their potential utility for pest management. J Pest Sci 89(3):621-630

51. Wakabayashi N, Cunningham RT (1991) Four-component synthetic food bait for attracting both sexes of the melon fly (Diptera: Tephritidae). J Econ Entomol 84(6):1672-1676

52. Venugopal V, Subaharan K (2019) Electrophysiological and behavioral response of red palm weevil, Rhynchophorus ferrugineus (Olivier) (Coleoptera: Dryophthoridae) to fermented coconut sap neera. J Plantation Crops 47(2):82-89.https://doi.org/10.25081/jpc.2019.v47.i2.5767

53. Audrain B, Farag MA, Ryu C-M, Ghigo J-M (2015) Role of bacterial volatile compounds in bacterial biology. FEMS Microbiol Rev 39(2):222-233

54. Ômura H, Honda K, Hayashi N (2000) Identification of feeding attractants in oak sap for adults of two nymphalid butterflies, Kaniska canace and Vanessa indica. Physiol Entomol 25(3):281-287

55. Haimanot T/Mariam (2015) Study on the Electrophysiological and Behavioral Responses of Bactrocera dorsalis, B. zonata, B. cucurbitae, B. oleae and C. capitata to protein lures. A Thesis presented to the School of Graduate Studies of Addis Ababa University in partial Fulfilment of the Degree of Masters of Science in Biology. https://pdfs.semanticscholar .org/8193/f56f92156a9f96655d33fof550fa8bddd4a1.pdf

56. Cruz A, Padilla-Martínez II, García-Báez EV (2012) A synthetic method to access symmetric and non-symmetric 2-(N, $N^{\prime}$-disubstituted) guanidinebenzothiazoles. Molecules 17(9):10178-10191

57. Tan KH, Nishida R, Jang EB, Shelly TE (2014) Pheromones, male lures, and trapping of tephritid fruit flies. In: Shelly T, Epsky N, Jang E, Reyes-Flores J, Vargas R (eds) Trapping and the detection, control, and regulation of tephritid fruit flies. Springer, Dordrecht. https://doi. org/10.1007/978-94-017-9193-9_2

58. Dugravot S, Mondy N, Mandon N, Thibout E (2005) Increased sulfur precursors and volatiles production by the leek Allium porrum in response to specialist insect attack. J Chem Ecol 31(6):1299-1314

59. Saguchi R, Hojo T (2017) Sustained release preparation comprising insect pest-targeting gel composition. In.: Google Patents

60. Hussein HM, Ubaid JM, Hameed IH (2016) Inscticidal activity of methanolic seeds extract of Ricinus communis on adult of Callosobruchus maculatus (coleopteran: brauchidae) and analysis of its phytochemical composition. Int J Pharmacogn Phytochem Res 8(8):1385-1397

61. Ando T, Yamakawa R (2015) Chiral methyl-branched pheromones. Nat Prod Rep 32(7):1007-1041

62. Andres VS, Ortego F, Castañera P (2007) Effects of gamma-irradiation on midgut proteolytic activity of the mediterranean fruit fly, Ceratitis capitata (Diptera: Tephritidae). Arch Insect Biochem Physiol 65(1):11-19 
63. Pirner GM (2018) Behavioral, physiological, and neurological influences of pheromones and interomones in domestic dogs. Pirner-Dissertation-2018.pdf. https://hdl.handle.net/2346/82084

64. Fernandes F, Pereira DM, de Pinho PG, Valentão P, Pereira JA, Bento A, Andrade PB (2009) Metabolic fate of dietary volatile compounds in Pieris brassicae. Microchem J 93(1):99-109

65. Krång A-S, Knaden M, Steck K, Hansson BS (2012) Transition from sea to land: olfactory function and constraints in the terrestrial hermit crab Coenobita clypeatus. Proc R Soc Biol Sci 279(1742):3510-3519

66. Krång A-S, Knaden M, Steck K, Hansson BS (2012) Transition from sea to land: olfactory function and constraints in the terrestrial hermit crab Coenobita clypeatus. Proc R Soc Biol Sci 279(1742):3510-3519. https://doi. org/10.1098/rspb.2012.0596

67. Kyerematen R, Adu-Acheampong S, Acquah-Lamptey D, Andersen RS, Owusu EH, Mantey J (2018) Butterfly diversity as indicator for environmental health within Tarkwa Gold Mine, Ghana. Environ Nat Resour Res 8:69-83. https://doi.org/10.5539/enrr.v8n3p69

68. Emmel TC, Larsen TB (1997) Butterfly diversity in Ghana, West Africa. Trop Lepidoptera Res 8:1-13

69. Sengonca C, Liu B (2003) Effect of GCSC-BtA biocide on abundance and diversity of some cabbage pests as well as their natural enemies in southeastern China. J Plant Dis Prot 110(5):484-491

70. Biasazin T, Chernet H, Herrera S, Bengtsson M, Karlsson M, Lemmen-Lechelt J, Dekker T (2018) Detection of volatile constituents from food lures by Tephritid fruit flies. Insects 9(3):119

71. Nganso BT, Kyerematen R, Obeng-Ofori D (2012) Diversity and abundance of butterfly species in the Abiriw and Odumante sacred groves in the Eastern Region of Ghana. Res Zool 2(5):38-46

72. Purvis A, Hector A (2000) Getting the measure of biodiversity. Nature 405(6783):212

73. Pinheiro CEG, Ortiz JVC (1992) Communities of fruit-feeding butterflies along a vegetation gradient in central Brazil. J Biogeogr 19:505-511. https ://doi.org/10.2307/2845769

74. Walther BA, Morand S (1998) Comparative performance of species richness estimation methods. Parasitology 116(4):395-405

75. Daily GC, Ehrlich PR (1995) Preservation of biodiversity in small rainforest patches: rapid evaluations using butterfly trapping. Biodivers Conserv 4(1):35-55

76. Leinonen R, Itämies J (2000) Notes of the moth fauna (Lepidoptera) in the Finnish Green belt zone as indicated by bait traps. Oulanka Reports 23:31-39

77. Süssenbach D, Fiedler K (1999) Noctuid moths attracted to fruit baits: testing models and methods of estimating species diversity. Nota Lepidopterologica 22:115-154

78. Eyer JR, Medler JT (1940) Attractiveness to codling moth of substances related to those elaborated by heterofermentative bacteria in baits. J Econ Entomol 33(6):933-940
79. Landolt PJ, Higbee BS (2002) Both sexes of the true armyworm (Lepidoptera: Noctuidae) trapped with the feeding attractant composed of acetic acid and 3-methyl-1-butanol. Florida Entomol 85(1):182-186

80. Landolt PJ, Alfaro JF (2001) Trapping Lacanobia subjuncta, Xestia nigrum, and Mamestra configurata (Lepidoptera: Noctuidae) with acetic acid and 3-methyl-1-butanol in controlled release dispensers. Environ Entomol 30(4):656-662

81. Landolt PJ, Hammond PC (2001) Trapping noctuid moths (Lepidoptera: Noctuidae) with acetic acid and isoamyl alcohol in Yakima County. J Lepid Soc, Washington

82. Iqbal W, Malik MF, Sarwar MK, Azam I, Iram N, Rashda A (2014) Role of housefly (Musca domestica, Diptera; Muscidae) as a disease vector; a review. J Entomol Zool Stud 2(2):159-163

83. El-Shafie HAF, Faleiro JR (2017) Semiochemicals and their potential use in pest management. Biological Control of Pest and Vector Insects. Chapter 1. https://doi.org/10.5772/66463

84. Nishida R (2002) Sequestration of defensive substances from plants by Lepidoptera. Annu Rev Entomol 47(1):57-92

85. Epsky ND, Kendra PE, Schnell EQ (2014) History and development of food-based attractants. In: Trapping and the detection, control, and regulation of tephritid fruit flies. Berlin: Springer, pp 75-118

86. Dressler RL (1982) Biology of the orchid bees (Euglossini). Annu Rev Ecol Syst 13(1):373-394

87. Mönkkönen M, Mutanen M (2003) Occurrence of moths in boreal forest corridors. Conserv Biol 17(2):468-475

88. Nyakeri EM, Ogola HJO, Amimo FA, Ayieko MA (2017) Comparison of the performance of different baiting attractants in the egg laying activity of the black soldier fly (Hermetia illucens L.). J Entomol Zool Stud 5(6):15831586. http://62.24.102.115:8080/xmlui/handle/123456789/1234

\section{Publisher's Note}

Springer Nature remains neutral with regard to jurisdictional claims in published maps and institutional affiliations.

Ready to submit your research? Choose BMC and benefit from

- fast, convenient online submission

- thorough peer review by experienced researchers in your field

- rapid publication on acceptance

- support for research data, including large and complex data types

- gold Open Access which fosters wider collaboration and increased citations

- maximum visibility for your research: over $100 \mathrm{M}$ website views per year

At BMC, research is always in progress.

Learn more biomedcentral.com/submissions 